\title{
AN ANALYSIS OF BANYUMAS DIALECT INFLUENCE TOWARD STUDENTS' ENGLISH PRONUNCIATION
}

\author{
Denta Naviantara, Suparno, Dewi Cahyaningrum \\ English Education Department \\ Teacher Training and Education Faculty \\ Sebelas Maret University
}

Email: dentanaviantara@gmail.com

\begin{abstract}
In using a foreign language, pronunciation is affected by learners' native language. English learners with Banyumas dialect will be distinctively recognized in their English. This present study is aimed to find out the differences in segmental features between Banyumas dialect and English and to describe the extent to which the Banyumas dialect influences students' English pronunciation. The research uses the descriptive qualitative method. There are 30 sources of data (students) from two different classes. The subjects are originally from Banyumas and use Banyumas dialect in their daily communication. The writer conducts English pronunciation tests and records the students' voices. The test includes 105 words consisting of each English vowels, consonants, and diphthongs. Besides, other supporting data are collected through document analysis, questionnaires, and observation. The study concludes that there are some differences in segmental features between Banyumas dialect and English, which have a negative influence on students' English pronunciation. There are many pronunciation errors found on students' pronunciation test results. Errors in pronunciation might be difficult to change if it becomes a habit. Teachers and students need to be aware of the differences between native language and foreign-language sound systems because it might be more valuable than error correction.
\end{abstract}

Keywords: Banyumas dialect, pronunciation, sound system.

\section{INTRODUCTION}

Pronunciation plays an essential role in delivering the words. Celce-Murcia (1996) states that intelligible pronunciation is one of the critical components of spoken communication. When one speaks English, he should pronounce the English words correctly. It is important to pronounce words correctly so that others can accept the message. If people do not know the pronunciation, they indeed fail in their communication - however, some English learners facing difficulties in English pronunciation. The problems might come from some factors. One of them is the impact of first language sound systems on students' English pronunciation.

Indonesia's official language is Bahasa Indonesia, so people do not use English in daily communication. There are also many regional languages can be found in Indonesia. Most Indonesians speak their local languages. One of the regional languages is Javanese, which is used to communicate with others in daily activities by people in Java. Because of the wide range of Java island, the Javanese language 
develops according to the geographic conditions. There are many regional dialects of Javanese language such as Banyumas, Solo, Surabaya, Samin, and Osing dialects (Soedjito, 1986; Paryono, 2011). Banyumas dialect is mainly spoken in Banyumas, Pekalongan, and Kedu residency.

In foreign language learning, the first language is essential. Learners with the Banyumas dialect will be distinctively recognized in their English pronunciation. Banyumas people tend to read words according to the written form. On the other hand, in English, there are some words omissions in pronunciation. Based on this assumption, the writer wants to find out the differences in segmental features between Banyumas dialect and English and to describe the extent to which Banyumas dialect influences students' English pronunciation. However, in this research, the writer focuses on the influence of Banyumas dialect on students' English pronunciation in the segmental aspects (vowels, consonants, and diphthongs).

\section{LITERATURE REVIEW}

According to Susan Boyer (2008, p.1), pronunciation is an oral communication which involves three important aspects such as producing correct sounds, knowing how the sounds are integrated, and understanding how to stress words and use intonation correctly. There are two aspects of pronunciation, segmental and suprasegmental features. Segmental features deal with the sound system of English (vowels and consonants) while suprasegmental features deal with prosodic features (stress, syllable, and intonation).

Harmer (2001, p.26) stated that Pronunciation is the knowledge of how to say a word. Furthermore, Yates (2002) in Gilakjani (2016) stated pronunciation is the production of sounds that are used for making meaning. The sound system of English is made up of phonemes to create words, sentences, or phrases for making meaning. Phonemes may be vowels, diphthongs, trip thongs, or consonants.

To sum up, it can be concluded that pronunciation is the knowledge to produce sounds of words used for making meaning. In this research, pronunciation is related to the way of vowels and consonants sound production. The stress, syllable, and intonation are ignored.

The sound system of English is made up of phonemes, or individual sounds which carry the potential to make meaning, and these may be vowels, diphthongs (the combination of two vowel sounds), triphthongs (the combination of three vowel sounds) or consonants. The English vowels are [i:], [r], [ひ], [u:], [æ], [ə], [e], [3:], [э:], $[\Lambda],[\mathrm{a}:],[\mathrm{p}]$, and the diphthongs are [ชə], [эг], [әे], [ег], [еә], [ат], [ај], [гә]. The English consonants are $[\mathrm{m}],[\mathrm{p}],[\mathrm{b}],[\mathrm{f}],[\mathrm{v}]$, $[ð],[\theta],[\mathrm{d}],[1],[\mathrm{n}],[\mathrm{t}],[\mathrm{s}],[\mathrm{z}],[\mathrm{r}],[\mathrm{t}]],[\mathrm{d}\}]$, [J], [3], [j], [k], [g], [y], [h], [w].

Reynaldi (2017) said that a dialect is a specific form of a language that is different from a specific region or social group. According to Chambers (2004, p.5), dialect refers to a variety which is grammatically (perhaps lexically) as well as phonologically different from other varieties. Moreover, Herusatoto (2008) said that dialect is a variation of a language that becomes basic of the development from a new form of vocabulary, accent, and idiom. Language can develop and make variation called dialect. The term dialect is often used to characterize a way of speaking that differs from the standard variety of the language. 
Based on the definitions above, it can be concluded that dialect is a variation of language in lexical, grammatical, and phonological systems. Dialect is closely related to an accent because they merge into one another to differentiate one language community from others.

Banyumas dialect is a variety of Javanese language that is used by people in Banyumas region, includes Banyumas regency, Pekalongan regency and western part of Kedu regency. Banyumas Dialect is popularly called Ngapak dialect. Ngapak language is the mother tongue of Banyumas people (Budiono, 2008). It is called ngapak because the spelling of some consonants and vowels [a] and [o] is very significantly clear. Banyumas dialect has six vowels: /a/, /i/, /u/, /o/, /e/, /a/ and 22 consonants /b/, /c/, /d/, $/ \mathrm{dh} /, / \mathrm{f} /, / \mathrm{g} /, / \mathrm{h} /, / \mathrm{j} /, / \mathrm{k} /, / 1 /, / \mathrm{m} /, / \mathrm{n} /, / \mathrm{l} /, / \mathrm{y} /$, /p/, /r/, /s/, /t/, /th/, /w/, /y/, and /?/.

\section{RESEARCH METHOD}

This research uses the descriptive qualitative method. The writer uses random cluster sampling. There are 30 subjects in two classes. This research is concerned with students' English pronunciation, especially in segmental aspects, including consonants and vowel systems of English and Banyumas dialect. In this study, the pronunciation aspect of being experimented is the pronunciation of individual and sequence of English segmental sound features. It includes sounds in English and Banyumas dialect.

Based on the research problem, the first data that the writer needs is the sound system of English and the Banyumas dialect that collected from documents. To find the first data, the writer conducts document analysis because the writer needs to make a comparison to find out the English sound features that do not exist in Banyumas dialect. This data will have formulated in the form of a list of English sounds that absent on Banyumas dialect.

The second data is about students' English pronunciation in the form of their pronunciation transcription. The students will take pronunciation tests and fill in a questionnaire. The writer also conducts an observation of students' English pronunciation.

The data of this research were analyzed by using the descriptive qualitative method. The writer used an interactive model of analysis involving data collection, data reduction, data display, and conclusions (Sutopo, 2002).

1. Data collection

In this step, the researcher prepares 105 English words for pronunciation tests. The words are chosen based on English vowels and consonants. The students will be asked to have pronunciation tests and fill in a questionnaire.

2. Data reduction

The researcher reduces the data which did not fulfill the needs. They are the data from the students who are not originally from Banyumas and who do not use the Banyumas dialect in their daily communication. The researcher selected 30 students based on the questionnaire results. All those 30 students are using Banyumas dialect in their daily communication.

3. Data display dan conclusion

In this step, the researcher presented the results and explained the data based on the analysis. Lastly, the researcher will draw a conclusion based on result of the study. 


\section{RESEARCH FINDINGS AND DISCUSSION}

1. Differences between English and Banyumas dialect sound system

There are some differences between English and Banyumas dialect sound system. The differences are (1) some English sounds are absent in Banyumas dialect sound system, (2) some Banyumas dialect sounds are missing in English sound system, and (3) some English sounds resemble Banyumas dialect sounds.

a. Some English sounds are absent in the Banyumas dialect sound system.

There are diphthongs in the English sound system. However, diphthongs do not exist in Banyumas dialect sound system. The diphthongs in English sound system are, [ひə], [эг], [əซ], [ег], [еә], [ar], [av], and [г]. The other English sounds that do not exist in Banyumas dialect sound system are, [v], [æ], and [a:].

b. Some Banyumas dialect sounds are absent in the English sound system.

There are some Banyumas dialect sounds absent in the English sound system. They are: [?], [y], [th $\mathrm{t}^{\mathrm{h}}$, $[\tilde{\mathrm{n}}]$, and $\left[\mathrm{d}^{\mathrm{h}}\right]$.

c. Some English sounds resemble Banyumas dialect sounds.

There are some seemingly the same sounds in English and Banyumas dialect sounds, but they are different in some features. The sounds are:

1) [t]] in English sounds and [c] in Banyumas dialect sounds.

Sound [ $\mathrm{t}]$ ] in English is similar to sound [c] in the Banyumas dialect. Based on the manner of articulation, sound [tf] in English is affricate while sound [c] in Banyumas dialect is stop.

2) [ð] in English sounds and [d] in Banyumas dialect sounds.

Sound [ð] in English is similar to sound [d] sound in the Banyumas dialect. Based on the manner of articulation, sound [ð] in English is fricative while sound [d] in Banyumas dialect is stop.

3) $[\theta]$ in English sounds and $[t]$ in Banyumas dialect sounds.

Sound $[\theta]$ in English is similar to sound $[\mathrm{t}]$ in the Banyumas dialect. Based on the manner of articulation, sound $[\theta]$ in English is fricative while sound $[\mathrm{t}]$ in Banyumas dialect is stop.

4) [d3] in English sounds and [j] in Banyumas dialect sounds.

Sound [d3] in English is similar to sound [j] in the Banyumas dialect. Based on the manner of articulation, sound [dz] in English is affricate while sound [j] in Banyumas dialect is stop.

5) [J] in English sounds and [s] in Banyumas dialect sounds.

Sound [S] in English is similar to sound [s] in Banyumas dialect. Based on the place of articulation, sound $[S]$ in English is palatal while sound [s] in Banyumas dialect is lamino alveolar.

6) [3] in English sounds and [s] in Banyumas dialect sounds.

Sound [3] in English is similar to sound [s] in Banyumas dialect. Based on the place of 
articulation, sound [3] in English is palatal while sound [s] in Banyumas dialect is lamino alveolar. Moreover, sound [3] in English is voiced while sound [s] in Banyumas dialect is voiceless.

2. The influence of Banyumas dialect toward students' English pronunciation

Banyumas dialect influences students' English pronunciation. The problems of English pronunciation are caused by (1) some Banyumas people is tendency to aloud read words as spelled, (2) the characteristics of Banyumas dialect sound system, (3) some English sounds resemblance Banyumas dialect sound system, and (4) some English sounds absence in Banyumas dialect sound system.

a. The characteristics of Banyumas people.

Cablaka is the characteristic of Banyumas people. Cablaka means the way to speak what the speaker wants to say immediately. In this case, cablaka influences Banyumas students' English pronunciation. The students tend to read the English words directly as spelled. In this research, there are 70 out of 105 words that the students pronounce as spelled. Those words are listed below.

b. The characteristics of the Banyumas dialect sound system.

The characteristics of Banyumas vowels and consonants sound also influence students' English pronunciation. The sounds are $[\mathrm{t}]$ and $[\mathrm{o}:]$.

1) Consonant $[t]$
Sound $[t]$ in the final position will be pronounced as [d] sound in Banyumas dialect sound system. Based on the result of the research, the word About should be pronounced as [əbavt] but 15 students pronounce About as [əbpud].

2) Vowel [o:]

Sound [o:] in open or closed syllable will be pronounced as [a] sound. There are 22 students in pronouncing Water, 4 students in pronouncing Tall, 17 students in pronouncing Walk. Sixteen students also pronounce [o:] sound as [av] sound when uttering the word August. It similarly happens to 29 students in pronouncing Awful, 23 students in pronouncing Applause, and 14 students in pronouncing "Clause".

c. English sound that resembles the Banyumas dialect sound system.

There are English sounds that resemble Banyumas dialect sound system. The sounds are as follows.

1) Sound [ð]

The students pronounce [ð] sound as [d] sound. The articulation of sound [ð] of English happens because the tip of the tongue is placed between upper and lower teeth. However, most students articulate [ð] sound as [d] sound. The articulation of [d] sound in Banyumas dialect sound system takes place between the tip of the tongue and the hard palate. This 
happens to students when pronouncing the word Feather, Father, Mother, and Together.

2) Sound [S]

Sound [S] in the English sound system resembles [s] sound in Banyumas dialect sound system. The students substitute [J] sound as [s] sound when pronouncing the word Patience, Institution, Sheet, and Special. The sound [J] in English sound system is pronounced by involving the blade of the tongue and hard palate with the main body of the tongue raised toward the roof of the mouth. On the other hand, in Banyumas dialect sound [s] is produced by involving the tongue and upper front teeth with the tip of the tongue resting behind the lower teeth.

3) Sound $[\theta]$

The students pronounce $[\theta]$ sound as [t] sound. This happens when the students pronouncing the word Through, Mouth, and Think. Sound [ $\theta]$ is made by the tongue is placed between the teeth while sound [t], in the Banyumas dialect sound system, is made by involving the tip of the tongue and upper teeth.

4) Sound [t $]$

Sound [ $\mathrm{t}]$ ] in English sound system resembles [c] sound in the Banyumas dialect sound system. When pronouncing the word Chess, Child, and Channel, the students replace sound [t $]$ with the nearest sound [c]. The articulation of $[\mathrm{t}]$ sound in English sound system is made with the blade of the tongue raised toward the roof of the mouth. However, [c] sound in Banyumas dialect sound system is produced by the obstruction of the airflow in the vocal tract with the middle of the tongue touching the hard palate.

5) Sound [d]

The students pronounce [dz] sound as [j] sound. This happens when the students are uttering the word Language, Jacket, and Knowledge. The sound [dz] in the English sound system is made by the tip of the tongue making contact with the roof of the mouth and then separates slightly. On the other hand, [j] sound in Banyumas dialect sound system is made by obstructing the airflow in the vocal tract and making it blocked entirely.

6) Sound [3]

Sound [3] in English sound system resembles [s] sound in the Banyumas dialect sound system. The students substitute [3] sound with [s] sound when pronouncing the word Pleasure and Unusual. The sound [3] in English sound system is pronounced by the blade of the tongue and the hard palate. In Banyumas dialect sound system, sound [s] is made by involving the tip of the tongue and upper front teeth. 
d. English sounds that absent in the Banyumas dialect sound system.

Some English sounds are absent in the Banyumas dialect sound system. The English sounds that are absent in Banyumas dialect sound system are [a:], [æ], [ஏə],

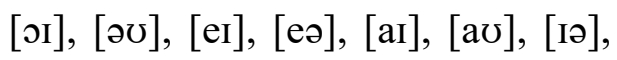
and $[\mathrm{v}]$.

1) Sound [a:]

The sound [a:] does not exist in Banyumas dialect sound system. The absence of [a:] sound in Banyumas dialect influence the students in pronouncing the word Half, Alarm, and Photograph. The students pronounce [a:] sound as [a] sound.

2) Sound [æ]

The sound [æ] is absent in Banyumas dialect sound system. The students substitute [æ] sound with [a] sound when pronouncing the word Maximum and Jacket. The students also replace [æ] sound with [e] sound in pronouncing the word Fan, Back, Bag, Man, And, Channel, Language, Cab, and Exam.

3) Sound [ซə]

The diphthong [चə] does not exist in the Banyumas dialect sound system. The absence of diphthong [ซə] in Banyumas dialect sound system influence the students in pronouncing the word Obscure and Tour. The students pronounce [ひə] sound as [च] sound.

4) Sound [or]
The diphthong [oI] is absent in the Banyumas dialect sound system. The students substitute [or] sound as [av] sound in pronouncing the word Lawyer. However, the students correctly pronounce [oI] sound in the word Toy.

5) Sound [əv]

The diphthong [əv] does not exist in Banyumas dialect sound system. The absence of diphthong [əo] in Banyumas dialect sound system influence the students in pronouncing the word Focus, Phone, Open, Know, Photograph, and Control. The students pronounce [əv] sound as [p] sound.

6) Sound [eI]

The diphthong [er] is absent in Banyumas dialect sound system. The students replace [eI] sound with [e] sound in pronouncing the word Behave and Make. Nevertheless, there are 16 students pronounce Day as spelled, [dar], instead of [deI]. Some students also pronounce Betray, Phase, and Nail wrongly as spelled.

7) Sound [eə]

The diphthong [eə] does not exist in the Banyumas dialect sound system. The absence of diphthong [eə] in Banyumas dialect sound system influence students in pronouncing the word Hair, Stairs, Prepare, and Pair. Most students pronounce the word Hair, Stairs, and Pair as spelled, 
[hair], [stairz], and [pair], instead of [heə(r)], [steərz], and [peər]. However, when pronouncing the word Prepare, the students pronounce [eə] sound as [e] sound.

8) Sound [ar]

The diphthong [aI] is absent in the Banyumas dialect sound system. This influences the students in pronouncing the word Violence, Write, and Die. Most students replace [aI] sound in the word Violence to [ID] as spelled in the word Violence. Most students also substitute [aI] sound with [i:] sound and [re] sound in the word Die. It means that the students pronounce the word Die as spelled. Not only Violence and Die, but most students also pronounce [aI] sound in the word Write as [I] sound.

9) Sound [av]

The diphthong [av] does not exist in the Banyumas dialect sound system. The absence of diphthong [av] in Banyumas dialect sound system influences the students in pronouncing the word How and About. Almost all of the students pronounce [av] sound in How and About as spelled, [pv] sound.

10) Sound [Iə]

The diphthong [I0] is absent in the Banyumas dialect sound system. This influences the students in pronouncing the word Fear and Area. The students replace [r] sound in
Fear with [I] sound and [e] sound. The students also substitute [Iə] sound in the word Area with [e] sound.

11) Sound [v]

The sound [v] is absent in Banyumas dialect sound system. However, there is no error in students' pronunciation results. Students pronounce sound [v] in the word Above and Every correctly.

\section{IMPLICATION}

This research can be implied that the Banyumas dialect has negative effects on students' English pronunciation. Students consider pronouncing English words as a difficult task to do since English is not their mother tongue. Students' mother tongue causes mispronunciation of many English words. Students tend to use their native sound system when pronouncing English words. It might be difficult to change if mispronunciation becomes a habit.

Pronunciation is about to talk intelligibly, which can be listened to and understood by others. However, learning pronunciation is not easy. Learning pronunciation needs an understanding of the differences between the native language and foreign-language sound systems. Teachers and learners should be aware of that because it might be more valuable than error correction.

\section{CONCLUSION AND SUGGESTION}

The writer presents the research conclusion following the two main findings of the research based on the two problem statements. First, there are some differences in segmental features between Banyumas 
dialect and English. The differences are (1) some English sounds resemble Banyumas dialect sounds, (2) some English sounds are absent in Banyumas dialect, and (3) some Banyumas dialect sounds are absent in English. The absences and differences in sound systems between the first language and the second language of learners give a negative impact on their second language learning. The learners tend to use their native language sound system when they speak their second language, as those languages have different sound systems.

Second, based on the result of the study, Banyumas dialect gives a negative influence on students' English pronunciation. There are many pronunciation errors found on students' pronunciation test results. The errors are caused by the way Banyumas people read words, some English sounds resemble Banyumas dialect sounds, and some English sounds are absent in the Banyumas dialect sound system. When Banyumas students found difficulties or unfamiliar with English words, they tend to read the word as spelled.

The researcher proposes some recommendations related to this research for teachers, students, and other researchers. The teacher should have taught English as early as possible so students' pronunciation errors could be minimized. Providing good teaching techniques, methods, media and an excellent model of pronunciation is essential in pronunciation practice. Teachers can also give feedback on students' pronunciation by giving students the chances to read English texts aloud. On the other hand, student should have high motivation to learn English, especially when pronouncing English words and reading English text. Students need to speak English actively and pay more attention to their pronunciation.
The next researchers are suggested to conduct further researches that choose the words that use contexts in a text or a passage. In order to get intelligible pronunciation, it would be so much better for further researches to ask native speakers to check the student's pronunciation. This might be better for the researcher to know whether student's pronunciation can be understood by a native speaker or not.

\section{BIBLIOGRAPHY}

Boyer, S. (2008). Understanding Spoken English: A Focus on Everyday Language in Context. Book Three. Boyer Educational Resources.

Celce-Murcia, et al. (1996). Teaching Pronunciation: A Reference for Teachers of English to Speakers of Other Languages. New York: Cambridge University Press.

Chambers, J.K. (2004). Dialectology (2 ${ }^{\text {nd }}$ ed.). Oxford: Oxford University Press.

Gilakjani, A.P. (2011). Why is Pronunciation so Difficult to LEARN?. English Language Teaching, 4 (3), 7481.

Harmer, J. (2001). How to Teach English. New York: Longman Ink.

Herusatoto, B. (2008). Banyumas: Sejarah, Budaya, Bahasa dan Watak. Yogyakarta: Kanisius.

Paryono, Yani. (2011). Keunikan Bahasa Jawa Dialek Banyumas sebagai Cerminan Identitas Masyarakat Banyumas. Retrieved from http://www.ki-demang.com/kongresbahasa-jawa-5 
Reynaldi, R.G. (2017). Phonological Differences between Standard Javanese and Banyumas Dialect of Javanese. Journal of Cultural, Literary, and Linguistic Studies, 1 (1).
Sutopo, H. B. (2002). Metodologi Penelitian Kualitatif. Surakarta: UNS Press. 